\title{
THE MAJOR SECTIONS OR GROUPS WITHIN SOBRALIA, WITH FOUR NEW SPECIES FROM PANAMA AND COSTA RICA, S. CRISPISSIMA, S. GLORIANA, S. MARIANNAE AND S. NUTANS
}

\author{
ROBERT L. DRESSLER
}

\begin{abstract}
Missouri Botanical Garden, Florida Museum of Natural History, Marie Selby Botanical Gardens Mailing address: 21305 NW 86th Ave., Micanopy, Florida 32667, U.S.A.
\end{abstract}

\begin{abstract}
Resumen. Se presenta una discusión de las secciones o grupos de Sobralia, basada en las secciones nombradas por Brieger. Se describen cuatro especies nuevas de Panamá y Costa Rica: S. gloriana, una especie escasa y muy llamativa del área de El Valle de Antón, pariente de S. atropubescens pero de flores más grandes y de coloración amarilla; $S$. mariannae, una planta pequeña del bosque nuboso de Cerro Jefe, con flores blancas y pelos gruesos en el labelo; S. crispissima, pariente cercana de $S$. lindleyana, que se extiende desde Panamá hasta el sur de México, y S. nutans, una especie distintiva de la Seccion Globosae, de Panamá.
\end{abstract}

ABSTRACT. The sectional classification of Sobralia is discussed, based on a system proposed by Brieger, and four new species of Sobralia are described from Panama and Costa Rica, S. crispissima, S. gloriana, S. nutans and S. mariannae.

Sobralia is a conspicuous element in the orchid flora of the American tropics that remains poorly known. The delicate, ephemeral flowers are often showy, but unless they are prepared carefully and dried quickly they make very poor pressed specimens. Even flowers in alcohol may disintegrate with time. Since botanical classification is traditionally based on dried material, Sobralia has been much neglected. To achieve a better understanding of this group, we should, ideally, study living material. The sectional classification is here discussed, and four new species from Panama and Costa Rica are described.

\section{THE SECTIONS AND GROUPS WITHIN SOBRALIA}

Lindley (1854) divided Sobralia into 3 sections, A, B and C. Reichenbach (1873) used the Sections Eusobralia and Brasolia for two South American groups, but the selection of S. dichotoma Ruiz \& Pavón as lectotype of the genus by Angely (1973: p. 1268) nullified this and made Section Brasolia Rchb.f. a synonym of Section Sobralia. Now, Brieger (1983) has published some additional sectional names, and names are now available at least for the three main groups listed by Lindley. Brieger's names are validly published and clearly typified, but there are several species and complexes that do not fit well in Brieger's classification. It might be premature to publish new sectional names at this time. That can wait until we have information on phylogeny from molecular studies.

Brieger separates Sections Sobralia and Racemosae by the position of the inflorescence, lateral in Sect. Sobralia and terminal in Racemosae. However, one may sometimes find both terminal and upper lateral inflorescences on the same stem. Dr. Dodson suggests the relative bract length as a much better and clearer way to distinguish what appear to be two distinct groups (pers. comm.).

Brieger (1983) creates a section Intermediae for $S$. fragrans Lindl., but that species seems closely allied to S. bletiae Rchb.f., S. mucronata Ames \& C. Schweinf. and others, so I tentatively apply the name Intermediae to a complex of species with smaller flowers and inflorescences. Brieger includes S. cro cea (Poepp. \& Endl.) Rchb.f. in Sect. Globosae, but it is very unlike $S$. candida, so I place it with the Intermediae for now.

It should be noted that the photograph labelled as S. fragrans in Brieger (1983), is actually S. callosa L.O. Williams, treated by Brieger as Lindsayella amabilis, while the photograph labelled as $S$. candida could well be $S$. fragrans.

The Section Abbreviatae is much the largest group, with perhaps 50 known species.

As here delimited, the members of Sobralia Section Globosae have narrow, acuminate leaves, the column is very narrow basally, and the bract cluster increases in length as flowers are produced, often 
reaching 3-4 $\mathrm{cm}$ in length. This group includes only a few species, treated in more detail below.

Sobralia luteola Rolfe, with a very condensed raceme, may be allied to Section Intermediae, though the inflorescence is strikingly different. Sobralia macrophylla Rchb.f. and its allies, with the bract cluster largely hidden, may not be a phylogenetic group, though the plants are easily recognized, with or without flowers. Sobralia undatocarinata C. Schweinf. and its allies, with loose bract clusters and 2-5 relatively durable flowers produced simultaneously, is quite distinctive, and a few close allies remain to be named. Both S. amabilis (Rchb.f.) L.O.
Williams and S. callosa (Lindsayella amabilis) are superficially similar and probably pollinated by hummingbirds, but they are very distinct in their details. Indeed, $S$. callosa has pollinia very like those of Elleanthus, and may have the best claim to generic status of any of the anomalous groups.

Ames and Schweinfurth (1937) emphasized the basal callus as being similar to the basal calli of Elleanthus, but nearly all species of Sobralia have a callus or a pair of calli at the base of the lip, on which the base of the column appears to rest; of course, the basal calli of Sobralia may well be homologous with those of Elleanthus.

\section{SUMMARY OF SECTIONS, ANOMALOUS GROUPS AND SPECIES}

1. Inflorescence racemose, with prominent internodes

2. Floral bracts shorter than pedicel and ovary

Section Sobralia [Type: S. dichotoma Ruiz \& Pavón, aprox. 13 species]

2 Floral bracts longer than pedicel and ovary

Section Racemosae Brieger [Type: S. rosea Poepp. \& Endl., aprox. 8 species]

1. Inflorescence condensed, with very short internodes

3. Rachis of inflorescence conic, exposed, with flowers and buds exposed simultaneously S. luteola

3. Rachis of inflorescence concealed by bracts, the bracts forming a cone-like structure

4. Bract clusters continuing growth, flowering over long period

5. Bract clusters growing in length

Section Globosae Brieger [Type: S. candida (Poepp. \& Endl.) Rchb.f., 3-4 species]

5. Bract clusters growing in girth S. valida

4. Bract clusters flowering only one season, not enlarging appreciably after flowering starts

6. Bract clusters basally concealed by sheaths of inflorescence bracts (upper leaves); the exposed apices of floral bracts wide, obtuse or retuse S. macrophylla complex

6. Bract clusters basally concealed or not; apices of floral bracts narrow, acute or acuminate

7. Bract clusters $3-6 \mathrm{~cm}$

8. Bract clusters compact, usually producing 1 flower at a time; tube of lip subequal to blade or longer Section Abbreviatae Brieger [Type: S. fimbriata Poepp. \& Endl., 45-50 species]

8. Bract clusters loose, often producing 2-several flowers simultaneously; tube of lip much shorter than blade

9. Lip with conspicuous undulate keels; all flowers at once, lasting 3-4 days

S. undatocarinata complex (3-5 species)

9. Lip without conspicuous, undulate keels; flowers ephemeral, 1-2 at a time S. amabilis

7. Bract clusters less than $2 \mathrm{~cm}$, usually producing 1 or 2 flowers at a time 10.Pollinia flattened, without distinct caudicles

Section Intermediae Brieger [Type S. fragrans Lindl., 10-15 species] 10.Pollinia obovoid, attached to distinct caudicles S. callosa (Lindsayella amabilis)

\section{NEW SPECIES}

Sobralia crispissima Dressler, sp. nov.

FIG. 1

HOLOTYPE: PANAMÁ. Chiriquí: al oeste de Volcán, carretera a Río Sereno; alt. 1200 m; 25 ago. 2001, sépalos y pétalos blancos, labelo amarillo-anaranjado con manchas rojas. A. Maduro \& E. Olmos 223 (MO, Isotypes, PMA, FLAS).
Sobraliae lindleyanae Rchb.f. similis, foliis majoribus et floribus brevioribus, labello reflexo margine valde undulato (crispo), marginibus falcatis appendicibus columnae integris dignoscenda.

Roots 6-8 mm in diameter; stems $20-40 \mathrm{~cm}$, ca. 5 $\mathrm{mm}$ wide, slightly compressed; sheaths striate; leaves 5 or $6,9-14 \times 3.5-5.4 \mathrm{~cm}$, ovate, slightly attenuate, acute; inflorescence terminal, with floral bracts con- 
cealed in infundibuliform sheaths of inflorescence bracts (upper leaves with reduced blades) with 1 or 2 additional reduced blades of floral bracts exposed, blade of lower inflorescence bract 7-11.5 x 2.2-3.5 $\mathrm{cm}$, blade of upper inflorescence bract ca. $2.5 \times 2 \mathrm{~cm}$; ovary and pedicel ca. $20 \mathrm{~mm}$. Sepals and petals white, lip orange-yellow with red spots; sepals 3.5-4.5 x 0.9$1.2 \mathrm{~cm}$, oblong or oblong-oblanceolate, apiculate; petals 3.5-4.5 x 1-1.5 cm, oblong-oblanceolate, obtuse or apiculate; lip 3-4 x 3-3.8 cm, broadly obovate, emarginate, blade strongly reflexed to near middle of tube, with a single rounded basal callus ca. 4.5 x $4 \mathrm{~mm}$, pilose distally, with 3 low ventral keels basally, margin of blade strongly crisped-undulate; column ca. $1.8 \mathrm{~cm}$, with porrect, falcate arms (or "wings").

Sobralia lindleyana Rchb.f. is common as terrestrial or lithophyte in the Llanos del Volcán, north of Hato del Volcán. This new and related species was recently found to the west of Volcán, in forested areas, and very similar plants without flowers were found to the east, usually growing epiphytically. When I noted that this species resembled S. lindleyana, Erick Olmos said "No, S. lindleyana is the species in the Llanos, its leaves are smaller and the flowers larger," which nicely summarizes the differences between these species. Reichenbach's drawing of $S$. lindleyana is suggestive of $S$. crispissima, but the type specimen is clearly the familiar species of the Llanos. The flowers of S. crispissima are somewhat smaller than those of $S$. lindleyana, and the tube is proportionately shorter. These plants may be distinguished from S. lindleyana by the following key.

1. Leaves 5-6 cm long; sepals and petals 5.5-6 cm long; tube of lip subequal to sepals and petals; blade of lip spreading, but not reflexed; column arm serratedentate dorsally S. lindleyana

1. Leaves 10-14 cm long; sepals and petals $3.5-5 \mathrm{~cm}$ long; tube of lip distinctly shorter than sepals and petals; blade of lip reflexed, reaching the middle of the tube; column arm entire dorsally S. crispissima

The epithet crispissima refers to the strongly wavy margins of the lip.

PARATYPES: MÉXICO. Chiapas: Ocosingo, ca. 8.5 km del camino Monte Líbano-Nahá, tomando el camino a Villa las Rosas y El Pozo Ocotal (PEMEX), aprox. $87.2 \mathrm{~km}$ al E de Ocosingo, ca. 940 $\mathrm{m}, 16^{\circ} 55^{\prime} \mathrm{N}, 91^{\circ} 33^{\prime} \mathrm{W}$, Selva mediana perennifolia, de montaña con Talauma, Quercus y Terminalia, sépalos y pétalos blancos, labelo amarillo con manchas café-rojizo, fecha de colecta 7 ago 1992, prensado de material cultivado 24 sept. 1997, M. A. Soto, R. Solano y L. Izquierda 6958 (AMO, FLAS). NiCARAGUA. Jinotega: Cerro Grande, elev. $3950 \mathrm{ft}$., Nov., A. A. Heller 1314 (SEL); Matagalpa: Finca Bavaria, 4100 ft., A. A. Heller 4980 (SEL). CostA RicA. Cartago: below Pavones on road from Turrialba to Siquirres, 25 Aug. 1963, C. H. Dodson 2516 (SEL).

Sobralia (Abbreviatae) gloriana Dressler, sp. nov.

FIG. 2, 3

HOlOTYPE: Panama. Coclé: Area de El Valle de Antón, Alt. 800-1000 m. 23 julio 2001, sépalos y pétalos amarillo pálido, bañados por rojo-castaño, bordes y vena media amarillos, labelo rojo-rosado con borde rosado pálido y quillas amarillas. A Maduro \& E. Olmos 212 (MO, Isotype PMA).

Herba epiphytica foliis ellipticis, floribus ab glomere bractearum conico-ellipsoideo productis, luteis, sepalis petalisque castaneo-ferrugineo aspersis, sepalis ellipticis vel lanceolato-ellipticis, petalis oblongolanceolatis, labello obovato quinque carinis humilis ornato.

Roots 3-5 mm in diameter; stems $20-80 \mathrm{~cm}, 2.5-4$ mm wide, slightly compressed; sheaths striate, with very short bristles to ca. $0.5 \mathrm{~mm}$ on both sheaths and stem; leaves several, 8.5-11 x 3.7-4.3 cm, elliptic, short-acuminate, strongly plicate; sheaths verruculose; inflorescence terminal, bract cluster ellipsoid, ca. 3 x $0.8 \mathrm{~cm}$, largely concealed by sheaths of upper leaves (or foliar bracts); ovary and pedicel $20-25 \mathrm{~mm}$; Sepals and petals pale yellow, flushed with purplish brick red, sepals with yellow median stripe, petals with broader median stripe and yellow margins, lip dull purple with yellow keels in throat; sepals 5-6 x 1.4-1.8 cm, elliptic or lance-elliptic, apiculate; petals 4-5 x 1.6-1.8 cm, oblong-oblanceolate; lip 5.2-6.2 x $3.5-4 \mathrm{~cm}$, cuneate, obovate, basal ridges $9 \times 2 \mathrm{~mm}$, with 5 low ventral keels, 3-4 of these reaching nearly to apex, margin distally undulate; column $2.6-3.2 \mathrm{~cm}$.

When I first saw this attractive Sobralia, I thought it might be a natural hybrid between $S$. atropubescens and some other species with yellow or white flowers. Now several plants of this kind have appeared, all from the area of El Valle de Antón, and it is surely a distinct species, though not very common. It is evidently related to $S$. atropubescens, but the flowers are larger and much more attractive with a distinct color 


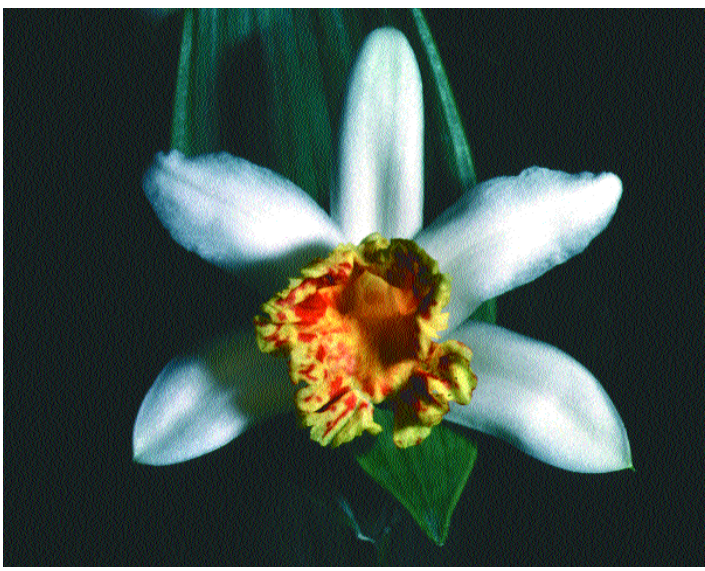

FIGURE 1. Sobralia crispissima Dressler. Flower, from the type locality. Photograph by K. Dressler.

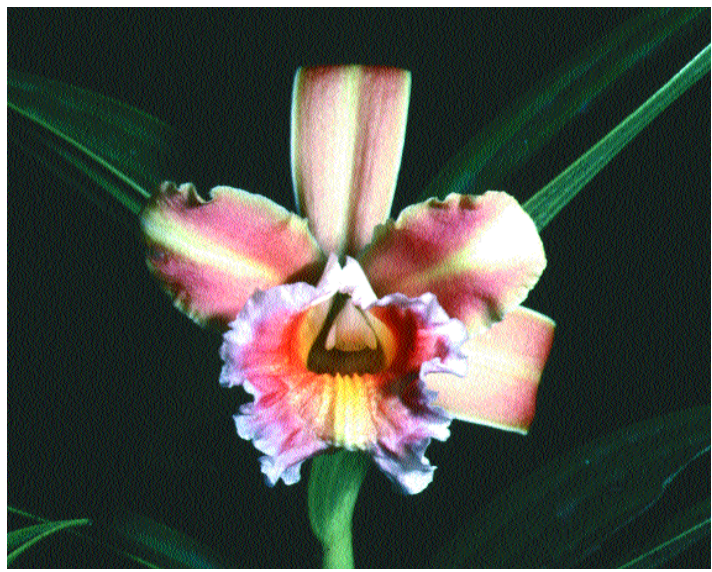

FIGURE 3. Sobralia gloriana Dressler. A flower cultivated in Florida. Photograph by K. Dressler.

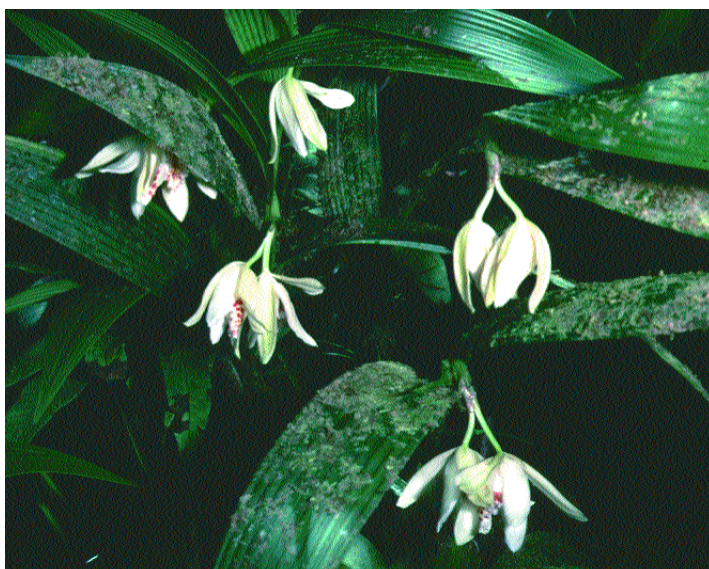

FIGURE 5. Sobralia nutans Dressler. Several inflorescences, some now form part of Maduro y Olmos 236 , Bocas del Toro, Panamá. Photograph by K. Dressler.

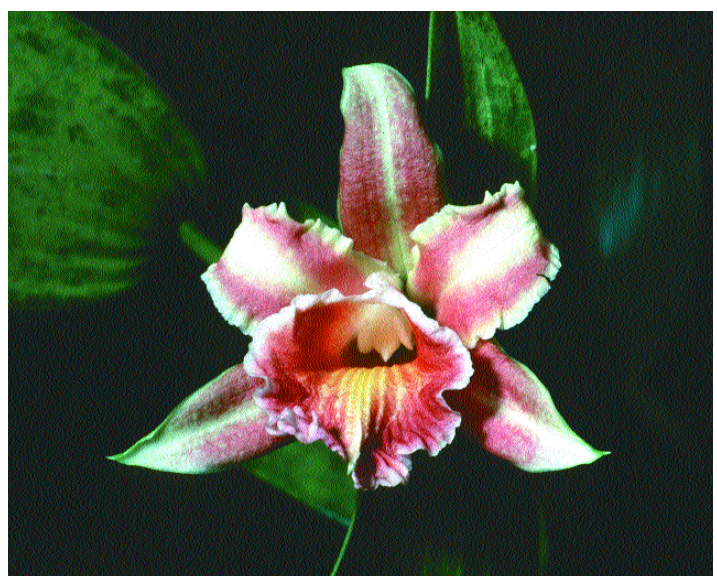

FIGURE 2. Sobralia gloriana Dressler. A flower, Finca Drácula, Panama. Photograph by K. Dressler.

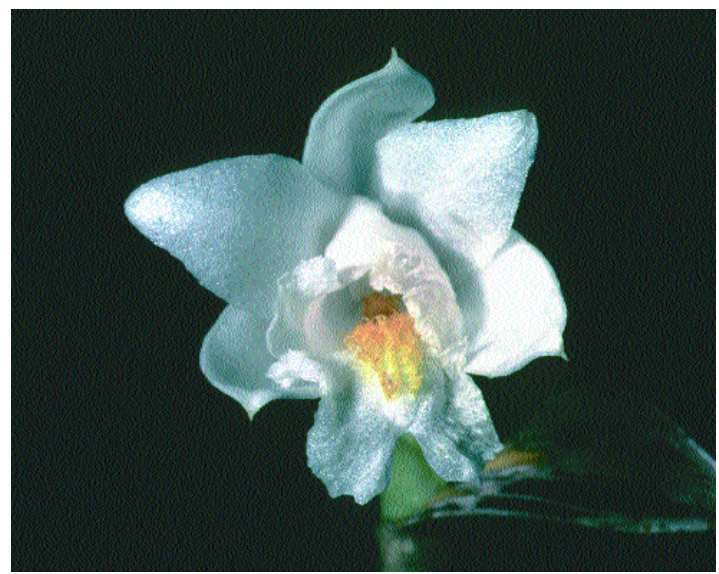

FIGURE 4. Sobralia mariannae Dressler. A flower, somewhat faded, Cerro Jefe, Panama. Photograph by K. Dressler.

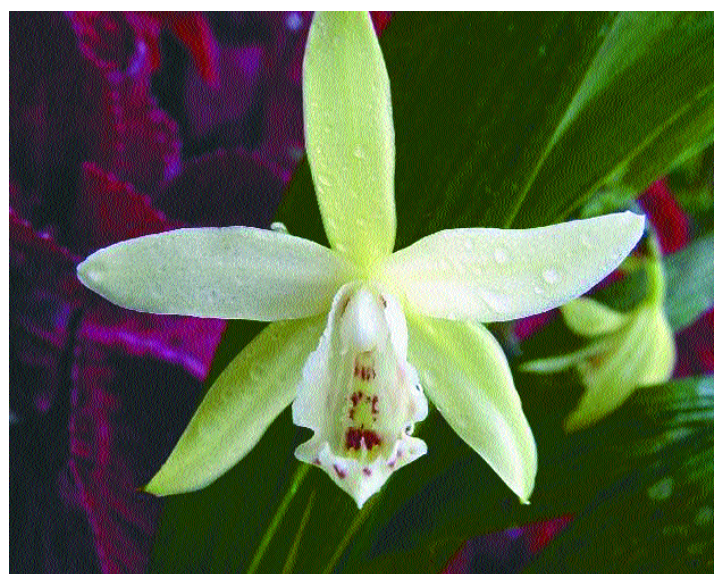

FIGURE 6. Sobralia nutans Dressler. Flower, El Valle Chiquito, near El Valle de Antón, Panama. Photograph by E. Olmos. 
pattern. One hopes that it will be propagated from seed, and become more widely available for orchid collections and gardens.

The epithet gloriana honors Licenciada Gloria Maduro, the charming wife of Andrés Maduro. Since she was foolish enough to marry a rabid orchid nut, she deserves, at the very least, that there be an attractive new species named in her honor.

Sobralia (Intermediae) mariannae Dressler, sp. nov.

FIG. 4

HOlOTYPE: Panama. Panamá, Cerro Jefe, flowered in cult. 24 May 2002, epiphyte, flower white, callus yellow, brown at base, fragrant, $R$. L. Dressler 6352, (MO).

Herba epiphytica caule supra medium foliato, foliis ovatis acuminatis, inflorescentia pedunculo superposita, sepalis oblongis, petalis ellipticis, labello obovato sex carinis trichomatibus crassiusculis quasi digitiformibus ornatis.

Epiphytic or terrestrial, caespitose, roots 1.5-2.5 $\mathrm{mm}$, stems $28-60 \times 0.15-0.2 \mathrm{~cm}$. Leaves $4.5-7 \times 1.5-2$ $\mathrm{cm}$, elliptic-ovate, acuminate, closely spaced at midstem and more widely spaced above; sheaths verrucose. Inflorescence terminal, with a reduced foliar bract (sometimes two) $2-3 \times 0.8-1.6 \mathrm{~cm}$ whose inflated sheath covers much of the bract cluster; bract cluster 2-2.5 x 0.4-0.5 cm, about half concealed by sheath of foliar bract, bracts glabrous; ovary and pedicel 15$22 \mathrm{~mm}$; flower white, callus yellow, brown at base; dorsal sepal $2.7 \times 0.67 \mathrm{~cm}$, oblong, apiculate; lateral sepals $2.5 \times 0.85 \mathrm{~cm}$, oblong-elliptic; petals 2.3-2.4 x $0.8 \mathrm{~cm}$, elliptic, acute or apiculate; lip $2.5 \times 2.1 \mathrm{~cm}$, broadly obovate, 3 -lobed distally, with 1 rounded basal callus, 6 yellow keels from base, these shortpilose, reaching near apex, midlobe $6 \times 11 \mathrm{~mm}$, retuse; column c. $8 \times 3 \mathrm{~mm}$.

This species is frequent in the cloud forest on Cerro Jefe. Until recently, we had only a field-collected plant in which the flowers are poorly preserved, but we have found a single flower in situ (photo) that was preserved in alcohol, permitting a much more complete description. Even without flowers, the plants are very distinctive, with the leaves closely spaced at mid-stem (1-3 cm apart), with a much longer internode $(6-10 \mathrm{~cm})$ above. This species, then, has a distinct peduncle, much like that of $S$. fragrans. This distinctive species may well occur in other areas of cloud forest in eastern Panama. The epithet honors Marianne Akers, an enthusiastic orchid student in Panama, who has collected the only other pressed specimen I have seen.

OTHER SPECIMEN SEEN: from the type locality, $M$. Akers 488-28 (SEL).

Sobralia (Globosae) nutans Dressler, sp. nov.

FIG. 5-7

HOlOTYPE: Panamá. Bocas del Toro: Km. 63, al norte de Fortuna, alt. 1050 m, 9 sep. 2001, terrestre; flores péndulas, blancas o crema, sépalos amarillentos por fuera, labelo crema con manchas rojo-castaño por fuera, por dentro amarillo en las quillas, con manchitas rojo-castaño. A. Maduro \& E. Olmos 236 (MO, Isotypes PMA, SEL).

Herba terrestris foliis ellipticis acuminatis, floribus pendulis ab glomere bractearum elongato in tempo crescenti productis, sepalis petalisque ellipticis, labello ovato obscure trilobato septem carinis ornato, tribus internis basi humili lobulis altis in apice, externis omnino crenato-undulatis.

Terrestrial, roots 3-5 $\mathrm{mm}$ in diameter; stems 60 $130 \mathrm{~cm}, 3-4 \mathrm{~mm}$ wide, slightly compressed; sheaths striate; leaves several, 20-36 x 2.5-4.7 cm, elliptic, acute to long-acuminate, strongly plicate; inflorescence terminal, gradually elongating, producing 1-3 pendent flowers at a time, to $4 \mathrm{~cm}$. long; ovary and pedicel $20-25 \mathrm{~mm}$; floral bracts c. 18 x 5-6 mm, lance-ovate, closely spaced; sepals at first yellowishgreen, petals and lip cream, lip with red-brown spots without, keels yellow with red-brown spots near midline; sepals $28-31 \times 8.6-10.5 \mathrm{~mm}$, elliptic, apiculate, lateral sepals carinate; petals $26-36 \times 8-10.5 \mathrm{~mm}$, elliptic, apiculate; lip 22-23 x $18 \mathrm{~mm}$, ovate, weakly 3-lobed, midlobe markedly undulate, with incurved margins; basal callus ca. 2 × 2 mm, 2-parted; keels 7, the 3 inner keels are low in the basal half and then form erect fin-like lobes $2-2.5 \mathrm{~mm}$ tall, to $4 \mathrm{~mm}$ long, there is then a crenate-undulate keel on each side, followed by a shorter, similar keel on each side; column c. $13 \mathrm{~mm}$, very narrow basally, c. 4 x $4 \mathrm{~mm}$ distally, wing-like teeth ca. 2 x $1.3 \mathrm{~mm}$, porrect; capsule 10.5 $\mathrm{x} 1 \mathrm{~cm}$.

In addition to the features given below in the key, $S$. nutans is rather larger than the other species of the section. The margins of the midlobe are somewhat folded in over the terminal lobes of the keels. The epithet, 


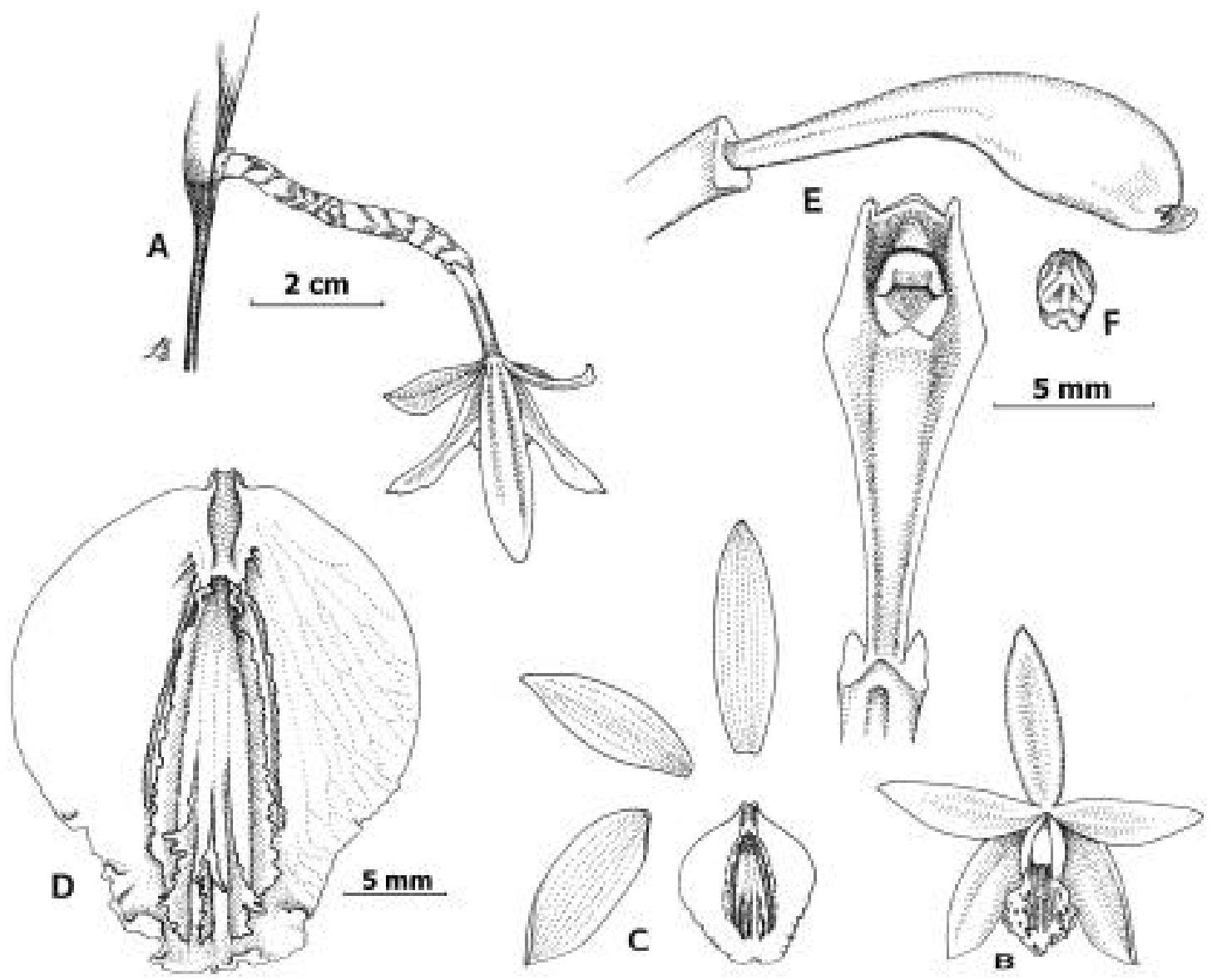

FIGURE 7. Sobralia nutans Dressler. A - Flower, natural position. B - Flower, front view. C - Flower parts, spread. D Lip, spread. E - Column, lateral and ventral views. F - Anther.

nutans, refers to the nodding, or pendent, flowers.

PARATYPES: PANAMA. Bocas del Toro: same area as type, 850 m, 27 Oct. 1999, R. L. Dressler \& J. T. Atwood 6256 (MO, PMA). Coclé: Vicinity of La Mesa, beyond El Valle, on northern slope of Cerro Gaital, $8^{\circ} 37^{\prime} \mathrm{N} 80^{\circ} 07^{\prime} \mathrm{W}, 850-950$ m, 12 July 1978, G. McPherson 11227 (MO); El Valle de Antón, La
Mesa, 4 mi. E of El Valle, $8^{\circ} 36^{\prime} \mathrm{N} 80^{\circ} 07^{\prime} \mathrm{W}, 25$ Mar. 1993, T. Croat 74806 (MO).

Better material from Costa Rica may show that Ingram \& Ferrell 813 and other Costa Rican specimens of the Section Globosae represent a species distinct from S. lancea, or that $S$. pardalina is a synonym of S. lancea.

\section{Key to THE SPECIES OF Section Globosae}

1. Lip distinctly pandurate, with 2 crenate or undulate keels

2. Leaves subcoriaceous; lip ecallose basally

S. lancea Garay [Costa Rica, Colombia, Ecuador]

2. Leaves thin, membranous; lip with "V"-like basal callus S. pardalina Garay [Ecuador]

1. Lip ovate or subovate, with 5-7 keels

3. Lip with 7 keels, outer 2 keels on each side prominent, crenate-dentate throughout, 3 inner keels low in basal halves with prominent, erect apical lobules S. nutans Dressler [Panama]

3. Lip with 5 low keels, all keels similar, dentate distally S. candida (Poepp. \& Endl.) Rchb.f. [Venezuela, Colombia, Ecuador, Peru, Bolivia] 
ACKNOWLEDGMENTS. I wish to thank Andrés Maduro and Erick Olmos for their help in finding material of these species, Franco Pupulin for his help with the Latin diagnoses, and Stig Dalström for the drawings of $S$. nutans.

\section{LITERATURE CITED}

Angely, J. 1973 (“1970”). Flora Analítica e Fitogeográfica do Estado de São Paulo, tomo 6. São Paulo.
Brieger, F. G. 1983. Subtribus Sobraliinae. In R. Schlechter, Die Orchideen, I, 13. Lieferung, eds. F. G. Brieger, R. Maatsch, K. Senghas. Verlag Paul Parey, Berlin \& Hamburg. p. 780-800.

Lindley, J. 1854. Folia Orchidacea, Sobralia. London, J. Matthews.

Reichenbach, H. G. 1862-1874. Xenia Orchidacea vol. 2. Leipzig, F. A., Brockhaus. 